\title{
A Központi Statisztikai Hivatal területi szerveinek történetéböl
}

Holka László,

a Központi Statisztikai Hivatal ny. vezető-fötanácsosa

E-mail:whokol@gmail.com
A KSH (Központi Statisztikai Hivatal) területi szervei Magyarország megyerendszerének átalakítása, a tervgazdaság bevezetése nyomán jöttek létre 1952ben. A visszatekintés ismerteti a megyei igazgatóságok és járási kirendeltségek létrejöttének politikai és hivatalszervezeti körülményeit, részletesen bemutatva keletkezéskori működésüket. A hivatalos statisztika szerepének későbbi módosulásait nyomon követve ismerteti szerepüket az adatgyüjtések végrehajtásában, növekvő feladataikat a tájékoztatás terén, kitérve kapcsolatukra a KSH központjával, egyben a munkájukat meghatározó személyi és tárgyi feltételek alakulására. Vázlatos képet nyújt az információs technológiák következtében megváltozott helyzetükről az 1990-es években, egészen a legutóbbi időkben bekövetkezett szervezeti átalakulásokig.

TÁRGYSZÓ:

Megyei igazgatóságok.

Statisztikatörténet.

DOI: 10.20311/stat2017.11-12.hu1082 
Helyi statisztikai szervezetek létesítését már Keleti Károly is szorgalmazta, első tervében indítványozta, hogy ún. „kültagok” tevékenységével az egész országot behálózzák a vármegyei statisztikai bizottságok, emellett programjába bekerült a városi statisztikai hivatalok ügye is. Ám elgondolásai kudarcba fulladtak, leszámítva a székesfőváros statisztikai szervének 1869. évi megalakítását. ${ }^{1}$ Nyolcvan év szünet után a területi szervek felállítása mégis megvalósult. Az 1949 augusztusában kikiáltott Magyar Népköztársaság gazdaságpolitikájában is követte a szovjet mintát, ennek eredményeként jöttek létre a KSH területi kirendeltségei.

Az 1949-es alkotmány új közigazgatást teremtett hazánkban: a központosított államhatalom helyi szerveiként létrehozta a tanácsokat. Kereteiket az alaptörvény nyomán 1949 és 1950 folyamán hozott jogszabályok szabták meg: a megyerendezés 25 , részben csonka vármegye helyett 19 újat teremtett, az alsóbb szinten 140 járással (átrendezésükkel esetenként törekedve egyfajta arányosságra, ezen belül a központok megközelíthetőségére). A korábban szolgabíró egyszemélyi vezetésével, testület nélkül müködő járások szerepe az új rendszerben megnőtt, első fokú feladatokra és hatáskörre tettek szert. Budapesthez hét várost és 16 községet csatoltak, így az ország 54 várossal rendelkezett. Az államigazgatás is a szovjet példa szerint alakult, önkormányzatiságot mellőző területi intézményei négy hónapon át mindössze tervként léteztek: csak 1950 januárjában született törvény róluk. Sőt, a frissen megalakult intézmények tagjai még kinevezéssel kerültek posztjukra, az első (kötött listás) „választásra” október 22-ig kellett várni. Az elöírások értelmében államhatalmi tevékenységet gyakorló tanácsok ülései között az 5-19 fös VB-k (Végrehajtó Bizottság) rendelkeztek az irányításiellenőrzési jogokkal. A közellátásról való gondoskodás mellett kiemelt feladatuk volt az állami és tervfegyelem megszilárdítása (akár büntető feljelentések révén). A tanácsok tehát a központosított államhatalom végrehajtói lettek.

A háború utáni újjáépítést a tervszerú „szocialista építés” követte, a törvénybe iktatott, 1947 és 1989 között 2 három-, és 7 ötéves tervnek megfelelően, amelyeket a legfelsőbb pártszervek állásfoglalásai alapján dolgozott ki az 1947-ben felállított OT (Országos Tervhivatal), amely létrehozását követően megkezdte a megyei tervkirendeltségek szervezését. Az országos terveket ágazati tárcánként lebontották, ami azzal járt, hogy a 3 ezer termékre kidolgozott központi elképzeléseket járási szintig részletezték, alsó szintủ végrehajtásukért idővel a járási tanácsok tervstatisztikai, később tervosztályai lettek felelösek.

A tervhivatal mellett 1949-töl 1952-ig létezett a kormányszintü feladatokkal megbízott NT (Népgazdasági Tanács) a minisztériumok, az OT és a KSH tevékeny-

\footnotetext{
${ }^{1}$ A fővárosi hivatal igazgatója 1869. december 8-tól 1906-ig, haláláig Körösy József volt.
} 
ségének összehangolására (megszünése után funkcióit az MT (Minisztertanács) vette át). Az aprólékosan kidolgozott népgazdasági terv piac híján nem kevésbé részletes visszacsatolást igényelt - derült ki a hároméves terv elszámolása és az 1950-ben megindítani szándékozott első ötéves terv előkészítése során. A KSH elsődleges feladata a terv nyomon követése lett. A megnövekedett államigazgatási feladatkörhöz igazodva a hivatal szervezete is tükrözte az ágazati tagolást: iparstatisztikai, mezőgazdasági, forgalomstatisztikai, népesedésstatisztikai, szociális- és kultúrstatisztikai szakfőosztályokat alakítottak ki.

Eközben másik ágon a miniszteriális adatérkeztetést érvényesítettek, rendeletileg minden gazdasági tárcánál létrehozva terv- és statisztikai részlegeket. Alulról felfelé haladó hierarchikus adatgyüjtési rendszert építettek ki, miközben a föösszesítés a KSH feladata volt. A statisztikai beszámolási rendszerről 1950-ben intézkedtek, ennek értelmében rendszeres statisztikai adatszolgáltatás csak a felügyelő szakminiszter és a KSH részére történhetett, az ezeket meghaladó rendszeres adatgyüjtéseket is a miniszter engedélyéhez kötötték - a végrehajtás ellenőrzésére még egy tárcaközi bizottságot is létrehoztak az NT titkársága, a KSH és az érintett tárcák képviselőiből. Ezzel együtt, a gazdaságirányítás adminisztratív jellegéből következően, az adatok iránt túlzott igény mutatkozott: az operatív vezetés 1952-től 60 iparcikk adatait naponta kérte be, hogy a tárca intézkedhessen a termelés folyamatosságának fenntartása érdekében.

A kialakulatlan gyakorlat buktatóit érzékelteti egy korabeli értékelés: „Az irányító szervek és a KSH a vállalatok és egyéb szervek végzett munkájáról beszámolójelentések útján értesülnek. Beszámolójelentés küldését az a szerv rendeli el, amelynek a vállalat müködésével kapcsolatos adatokra szüksége van. Kezdetben se szeri, se száma nem volt a legkülönbözőbb és bátran lehet mondani, néha a leglehetetlenebb adatok kérésének. (...) A kontárstatisztika bürokratikus jellege miatt meggátolja a statisztikát egyik alapvető feladatának teljesítésében, a tervteljesítés ellenőrzésében." (Pálos [1952]). A járatlanság némiképp kaotikussá tette az adatokkal való gazdálkodást. A káoszt valószínüleg nemcsak az alulinformáltságot kimutatásokkal leküzdeni kívánók okozták, hanem az is, hogy az igénylők „tényszámokkal” kívánták bebiztosítani magukat az esetleges kellemetlen következményekkel szemben.

Az adatminőség javítására az NT már 1949-ben kitüzte a megyei statisztikai kirendeltségek létrehozásának célját (290/15/1949 sz. határozat), majd egy következő rendeletében az alispáni hivataloknál (az alispáni tisztséget az 1950. évi I. törvény szüntette meg) 3-5 fővel létesítendő új szervezetek feladatkörét az országos és helyi adatgyüjtések megszervezésében, ellenőrzésében, feldolgozásában és értékelésében szabta meg. Baranyában például „1949 végén jelentek meg a Központi Statisztikai Hivatal szervezői (Ugocsai Antal és Pesti Lajos) a megyében, és a Megyei Tervkirendeltség akkori vezetöjével, Sziebl Antallal együtt kezdték szervezni a Központi Statisztikai Hivatal önálló megyei Kirendeltségét. 1950. január elsejével megkezdte 
müködését a Baranya megyei Kirendeltség...” $(K S H \text { [1987a]) })^{2}$ Irányításukra a KSH-ban felügyeleti osztály alakult, amely az Elnöki föosztályhoz tartozás rövid kitérője után a Mezőgazdasági főosztályhoz került, majd Felügyeleti főosztály néven önállósult. A megyei tanácsok 1950. júniusi megalakulását követően a statisztikai kirendeltségek beolvadtak a megyei VB-k rendszerint 11 osztályból álló apparátusába, s a korabeli sorszám szerinti II., Terv- és statisztikai osztályok részei lettek. A KSH szerepét az NT ekkor a munka elvi irányításában és ellenőrzésében szabta meg. Így 1951 utolsó napjaiban a Magyar Dolgozók Pártja államigazgatási osztálya módosított a felfogáson, s inkább a ,járásokig lenyúló, független statisztikai szervezet kiépítésében" látta a megoldást, célszerübbnek tartva megszüntetni a statisztikusok kettős alárendeltségét. Ezután az MT vette kézbe a változtatás ügyét: a következö év februárjában hozott egy ennek megfelelő határozatot (2021/6/1952 MT), majd kiadta annak végrehajtási utasítását, az új szervek létesítésének határidejeként április 1-jét jelölve meg. Ily módon a KSH területi részlegeinek megvalósítására irányuló intézkedések jóval megelözték az 1952. évi VI. - december 20-án elfogadott, sorrendben a negyedik - statisztikai törvényt. A jogszabály 6 . §-a részletezte a helyi képviseletek ügyét, ennek értelmében a KSH területi szervei megyei igazgatóságokból, valamint járási és városi felügyelőségekből álltak. A megyék irányítását a hivatal központja, a járásokét és a városokét a megyei igazgatóságok látták el; hogy kivédjék a helyi befolyásolás lehetőségét, a tanácsok nem jutottak szerephez. Létrejött a KSH kihelyezett, integráns részét alkotó területi apparátusa.

Budapest Székesfőváros Statisztikai Hivatala átalakult fővárosi igazgatósággá, élére Pesti Lajos (1925-2013) került. Öt 1948-as elnöki kinevezése után az OTI-tól (Országos Társadalombiztosítási Intézet) negyedmagával együtt hívta át a KSH-ba Péter György (1903-1969). Pesti Lajos az igazgatóságot 1961-ig vezette, ezt követöen a hivatal elnökhelyetteseként a számítástechnika fejlesztését gondozta (országos méretekben is).

A területi egységek szervezése 1952. április 1-jétől az év végéig tartott: addigra már működött a 19 megyei és a fővárosi igazgatóság, összesen 1140 fövel; ezen belül a 161 járási és városi felügyelőség 499 fövel végezte munkáját. Rövid közjátékként a megyei jogot kapott Debrecenben, Miskolcon, Pécsett és Szegeden 1955-ben mindössze négy hónapig városi igazgatóságok is életre keltek, majd beolvadtak a megyei igazgatóságokba. Szeged kivételével, ahol a városi igazgatóság öt évvel később csak papíron szünt meg, ténylegesen még másfél évig dolgozott. Ugyanebben az évben élte át a hivatal az államigazgatás egészét érintő első létszámcsökkentést, ami a területi szerveket 10 százalékos mértékben érintette; a második hasonló intézkedés 1957 tavaszán már 15-20 százalékos leépítést eredményezett. Így azután 1962 végén a

\footnotetext{
${ }^{2}$ A területi szervek 35 éves évfordulójának tiszteletére 1987-ben minden megyei igazgatóság egyedi szerkezetben összeállította saját történetét megörökítő kiadványát. A forrásanyagok elérhetők a KSH Könyvtárban.
} 
területi egységek létszáma 1067 före apadt (közülük a felügyelőségeken 430 fő dolgozott). Az igazgatóságok létszáma az idők folyamán a feladatok függvényében is ingadozott, mégis az indulás évei lehettek a legnehezebbek: Vas megyében az első öt évben a kezdő állomány 80 százaléka kicserélődött ( $K S H$ [1987b]). A területi részlegek összlétszáma a későbbiekben nem sokat változott: a KSH megyei igazgatóságainak gyökeres átszervezése előtt, az ezredfordulón elvégzett szakértői vizsgálat náluk 995 föt talált a hivatal akkori, 1986 fős összlétszámából (Fellegi-Ryten [2002]).

A 2000-es évek elején a kirendeltségek létszáma megyénként 45 fö körüli volt (függetlenül a megye nagyságától, adottságaitól vagy iparosodásának szintjétől), a munkatársak kétharmada adatgyüjtéssel, 12 százalékuk tájékoztatással és a felhasználók támogatásával foglalkozott. Kezdetben az igazgatóságok döntő többségénél (a kirendeltségekkel együtt) 30-60 munkatárs dolgozott, az 1952. év végi állapot szerint a legnépesebb a Borsod-Abaúj-Zemplén megyei (74 fö, ahol egyébként „nehéz volt a három megyéből egyet kovácsolni”, illetve a Fővárosi Igazgatóság (44 fö) volt, a legkisebbek közé a Nógrád megyei (33 fö) és a Komárom megyei ${ }^{3}$ (30 fö) tartozott. (KSH [1987c]).

A KSH központjának irányítási kereteit az 1952-ben született szervezeti és müködési szabályzat adta meg, módosításai során csiszolva a központ és a területi szervek közötti munkamegosztást. Az adatgyüjtés, -ellenőrzés, valamint -feldolgozás a tervnek megfelelően történt, a tájékoztatásban a hivatalban érvényesülő rend követése volt a követelmény. A munkatársak alkalmazásának jogát a következő évben a KSH elnökétől a megyei vezetőkhöz utalták. A kezdeti túlzottan központosított irányítás lassan oldódott; idővel az igazgatóságok a központi munkatervben meghatározott feladatokat az adottságaiknak leginkább megfelelő szervezéssel és módszerekkel végezhették el. A rendszeres munka megindulását a központ eleinte instruktori hálózattal segítette, amely fokozatosan háttérbe szorult, csupán a teljes körü összeírásoknál bukkant fel ismét. Helyébe a négy-öt igazgatóságot felügyelő megyei föellenőri rendszer lépett, amely az 1950-es évek derekától 1985-ig 4-5 évenként átfogó ellenőrzésnek vetette alá a területi szervezeteket; ennek helyébe léptek az igazgatóságok féléves, éves tevékenységét ismertető felügyelő főosztály összefoglalói. A munka egyeztetését a rendszeresen megtartott igazgatói értekezletek szolgálták - miközben a felügyeletet ellátó területi statisztikai főosztály értekezleteket tartott a tájékoztatási, számítástechnikai és gazdasági osztályvezetők bevonásával. A területi szervezetek munkájával rendszeresen foglalkozott a hivatal vezetői kollégiuma (később föosztályvezetői értekezlete), és iránymutatást adtak az év elején megrendezett hivatali nagyaktívák.

A megalakulást követően megjelent müködési szabályzat értelmében a kirendeltségek élén a KSH elnöke által megbízott vezető állt, a munkát a feladatok szerint alakult csoportok végezték el. Az igazgatóságok részlegeinek osztályok szerinti tagolása 1965ben következett be, ami a későbbi felállás alapját is jelentette (ekkortól a megyei szer-

\footnotetext{
${ }^{3}$ Ezen a néven 1990. évig, amikor négy megyét átneveztek.
} 
vezeti struktúra jellemzően: igazgató; gazdasági önálló csoport vagy osztály; tájékoztatási, szervezési, feldolgozási, összeírási osztályok, valamint a felügyelőségek).

Miközben 1965-ben az igazgatóságok országszerte szervezeti rendjük átalakításával, az osztályok és csoportok felállításával foglalatoskodtak, Komáromban rendkívüli esemény következett be: az igazgatóság megszünt. (Előélete egyébként is kissé hányatott volt: Esztergomban alakult, $\mathrm{s}$ alig félévre rá Tatabányára települt át). Felszámolásának okát a megye társadalmi-politikai szerveinek irányítói és az igazgató közötti személyes ellentétekben jelölték meg. A részleg feladatait a Fejér megyei igazgatóság vette át, négy Komárom megyei munkatárssal együtt (két-két fő a győri és a pesti igazgatóságra, egy pedig a KSH központjába került, a többiek más intézményeknél folytatták munkájukat), egészen 1970-ig, amikor a népszámlálás munkálatai közben újjászervezték a Komárom megyei részleget (ekkor került Tatabányára Helt Ferenc, a KSH későbbi elnökhelyettese).

Bár az MT 1952-es határozata úgy szólt, hogy statisztikai munkakört csak megfelelő végzettséggel rendelkező egyének tölthetnek be, az indulás évében szakmai képzettségröl nemigen lehetett beszélni. Tanfolyami képzéseket azt megelőzően nem tartottak, ritka volt a megfelelő ismereteket oktató középiskola, felsőfokú tanintézmény is. A tanácsoktól átkerült munkatársakon kívül a létszámfejlesztésben elsősorban a felszabadulás után középiskolát végző munkás-paraszt származásúakkal, valamint a vállalatoktól „kiemelt” 8 általános iskolai végzettséggel rendelkező fiatal fizikai dolgozókkal számoltak. Az utóbbiak aránya az alapítás évének végén a létszám 40 százaléka volt. A felsőfokú végzettségủek alig 5 százalékot tettek ki (33 évvel később arányuk 25,2 százalékra nőtt). Mindennek következtében előtérbe került a képzés és a továbbképzés; előbb 1951-től egyéni tanulásra alapozva, egyéves tanfolyamokkal, majd hathetes bentlakásos kurzussal, amely a következő évben tízhetessé, később kéthónapossá bővült, legalább középfokú statisztikai ismeretekkel vértezve fel a hallgatókat. A megyei igazgatóságok munkatársai közül 1953-ban és 1954-ben számosan részt vettek 10 hónapos, illetve egyéves káderképző iskolák oktatásain. Az MT határozatának megfelelően három közgazdasági technikumot átszerveztek statisztikaivá, a KSH szervezetéhez csatolva ezeket. Idővel a Marx Károly Közgazdasági Egyetemen megindult a statisztikus szakközgazdász-képzés, az 1971-től meghirdetett új szakra 15 igazgatósági dolgozó jelentkezett.

\section{Az adatgyưjitések}

A tervek megalapozása és végrehajtásának ellenőrzése hallatlan szükségletet gerjesztett az adatok iránt. A helyi szintủ adatgyüjtés letéteményesei a megyei és járási 
statisztikai részlegek lettek. Kezdetben a központ számára az igazgatóságok adatgyüjtései és feldolgozásai lényegében csak a más csatornákon beérkező adatok ellenőrzése szempontjából minősült fontosnak, a területi szervek pedig igen szerény területi bontásokat kaptak. Az iparosodást központi akarattal megkezdő agrárországban a mezőgazdasági felvételek álltak előtérben. A „szocializmus alapjainak lerakása” a mezőgazdaságban termelőszövetkezetek alakítását (a kollektivizmus jegyében), továbbá állami gazdaságok létrehozását jelentette (a nagyüzemi gazdálkodás előnyeinek kidomborítási szándékával). Az egyéni gazdálkodók, később mindinkább a termelőszövetkezetek vonóerő-szükségleteinek ellátását szolgálták az 1948-as kormányrendelettel állami tulajdonba vett mezőgazdasági gépállományt Magyar Állami Mezőgazdasági Gépüzem néven müködtető gépállomások; a költségvetésből gazdálkodó egységek száma 1951-ben 368 teleppel tetőzött (a mezőgazdasági gépeknek ezt az állami monopóliumát 1957-ben szüntették meg, lehetővé téve gépek vásárlását a tsz-ek számára is). Ezek mindegyike újdonságot jelentett az üzemgazdaságban, nyilvántartási hagyományok nélkül, gyenge számviteli fegyelemmel, járatlan utakon haladtak. „A földosztás gyökeresen megbolygatta a művelés alá vont területek elhelyezkedését és nagyságát, a községi jegyzők adatszolgáltatásaira támaszkodó kimutatásokból mást olvastak ki a pénzügyi, mást a földmüvelési és megint mást a begyüjtésért felelős szervek" (Mód [1951]). A magángazdaságokat pedig megrettentették a tevékenységükre vonatkozó tudakozódások - holott a tervlebontás rájuk is vonatkozott, a községekre lebontott, elsősorban a gabonafélékre összpontosító tervek próbálták az ország agrártermelését mederbe terelni.

Az ágazat felderítésére az OT, a mezőgazdasági tárca és a KSH az 1949. novemberi állapotnak megfelelően elvégzett egy országos felvételt az állami gazdaságok és az újonnan szerveződő termelőszövetkezeti csoportok (nagyüzemek) helyzetéről. A részletes, üzemi adatokat felmérő kérdőíves felvételt a megyei közigazgatással, a 45 állami gazdasági központtal és a helyi gépállomásokkal közösen szervezték meg. Ezeket a nagyüzemeket a későbbiekben, 1950-től havi adatszolgáltatási kötelezettség terhelte. A felmérés után 1950 februárjában országos állatösszeírást hajtottak végre, aminek pontosságát a KSH egy hónappal később szuperrevízióval a községek 10 százalékára kiterjedően ellenőrizte.

Az 1950. évi MT-rendelet a KSH feladatává tette az egységes mezőgazdasági nyilvántartási rendszer kidolgozását és bevezetését, amely kiterjedt a mezőgazdasági müvelés alatt álló, 400 négyszögölnél nagyobb ingatlanok birtokosaira. A termelést folyamatában vizsgálni kívánó elképzeléseket (vetés, cséplés, betakarítás) még abban az évben, vetés idején próbálták valóra váltani az újonnan létesített tanácsok közremüködésével. A kiigazítás jellemző módon úgy történt, hogy végül az 1951. évi öszi vetésterületi összeírások során a községi beszámolókat a terv mérésére alkalmas változatban is el kellett készíteni, összesen másfél millió gazdaságra, amihez ezer fővel megerősítették a tanácsi apparátust. Még lényegesebb vetületként a beadási kötelezettségeknek is ez lett az alapja 
(az államnak 1946 és 1956 között a gazdálkodók megszabott mennyiségű és árú mezögazdasági terményt kellett kötelezően leadniuk, a beadási kötelezettségek teljesítésében a beszolgáltatás eleinte a harmadik helyen állt a fejadag és a vetőmag biztosítása után, majd 1952-re az első helyre lépett elő, a fejadag lett a harmadik).

A tanácsokkal közösen dolgozó statisztikusok erőivel végezték el 1951 januárjában a kisiparosok, magánkereskedők összeírását, amit ettől az évtől kezdődően községenként a helyi tanácsok összeállításában, éves kimutatásokban rögzítettek, telepek, üzemek, üzletek szerint. Az ország minden helységére kiterjedő művelet keretében 1950 júliusában, majd 1952 márciusában a települések fejlettségnek, ellátottságának feltárását „helyzetkép-statisztikai” adatgyüjtés szolgálta, amit korabeli területfejlesztési megfontolásokból hajtottak végre (Dányi-Nyitrai [1998]).

A háborút követő újjáépítés utáni ínséges években kivételes fontosságra tett szert a termésbecslés. Az NT döntésével a KSH-ban létrehoztak egy termésbecslési osztályt, amely megszervezte a megyei szinten függetlenített szakemberek hálózatát, így 1952. április 1-je után minden megyei és járási kirendeltségen dolgozott egy termésbecslő. A helyszínen végzett „reprezentatív” becslést követő eljárás alapvető eszköze a mérőlánc volt a táblák szemrevételezéséhez, valamint egy négyzetméteres keret. Az utóbbival megszámolták a kalászokat, majd a kalászokban a szemeket, amit felszorozva megkapták a becslés eredményét. Egy kortárs résztvevő beszámolója szerint, míg az operatív jelentések 110 százalékos teljesítésekről szóltak, a statisztikusok számításai „nyolcvanegynéhány, maximum 90 százalékot” mutattak (Marosi [2010]). A termésbecslők azonban csak átmenetileg voltak a hivatal kötelékében, mivel az MT 1953-ban létrehozta az Állami Termésbecslési Felügyeletet a Földművelésügyi Minisztérium égisze alatt.

A termésbecsléstől eltérően a gazdalajstromok vezetésében való közreműködés megmaradt a KSH megyei és járási statisztikusainak feladatai között. Az állami terménybegyüjtést egy 1950. évi MT-rendelet szabályozta, ennek megfelelően a községi elöljárók minden községi vagy városi földkönyvben szereplő személyről adatlapot vettek fel, amelyet változási jegyzék kísért. A kettő alapján állították össze a gazdalajstromot és egy nyilvántartási lapot, ebben tüntették fel a terménybeadási kötelezettségeket. Később, 1954-ben a városokban önálló begyüjtési hivatalokat, a községekben megbízotti szervezeteket létesítettek (a kötelező beadás megszüntetését 1956ban a XXI. törvény mondta ki). A statisztikusok számára hasonlóképpen évente elvégzett feladat maradt a tavaszi vetésterület teljes körü felmérése, egészen 1963-ig (amit a kisgazdaságok reprezentatív megfigyelése, majd 1980-tól szakértői bizottsági becslések váltottak fel). Egyetlen esztendő kivételével 1950-től 1973-ig minden évben teljes körü volt az állatszámlálás - akárcsak a vetésterület esetében -, a kisgazdaságok állományának felmérését az igazgatóságok szervezték és irányították. A teljes körü felvételek száma 1973 után csökkent, cserébe gyakoribbá váltak, évi négy alkalommal hajtottak végre reprezentatív megfigyeléseket. 
A mezőgazdaságra vonatkozó egyszeri megfigyelések sorában merőben szokatlan feladatot képviselt a gyümölcsfák 1959-1960-as teljes körü felmérése: az összeírók az addigra már megszokott kérdezéses módszer helyett - térképszelvények alapján, községröl-községre haladva, a helyszínen számlálták meg a fákat, rendszerint járásonként 3-5 fös brigádokba tömörülve. (Hasonló összeírásra 1971-ben reprezentatív eljárással került sor, kivéve Szabolcs-Szatmár megyét, ahol a jelentős gyümölcstermesztés miatt teljeskörüen végezték el.) Ugyancsak terepmunkát igényelt az 1960-as évek derekán két hullámban lebonyolított szőlöösszeírás.

Az iparstatisztikai adatok területi feldolgozását 1952. január hónappal kezdték meg. Az akkori területi statisztikai kérdőívek csak a legfontosabb adatokat tartalmazták; ez előbb hat, 1954 második felétől már csak három mutatóból állt. A területi igazgatóságok adatfeldolgozási és -közlési munkájának kiépítésével elvesztette jelentőségét a hivatal központjának területiadat-feldolgozása. Erre tekintettel a KSH vezetése a párhuzamos feldolgozást az ötvenes évek második felében megszüntette; a területi statisztikai szervezetek adatgyüjtési tevékenységének összehangolására 1952 első félévében külön szervezeti egységet állított fel. Első összeírási feladataként a negyedik negyedévben anyagkészlet-felvételt hajtottak végre, ezt követte a kisiparosok, kiskereskedők, valamint a mezőgazdaságban alkalmazott gépek számbavétele.

\section{Gazdasági reformok}

Az 1960-as évek második felében a gazdaságirányítási rendszer reformja, az új gazdasági mechanizmus előkészületeivel összefüggésben fokozatosan lazult a tervezés és a statisztika kapcsolata: a tervfeladatok (a kenyérgabona kivételével) lebontása a tanácsi szervekre 1966-tól megszünt, véget ért a tanácsok tervet jóváhagyó hatásköre, s az 1967. évi termelöszövetkezeti törvény megszüntette a tervkötelezettséget is (a gépállomásokat 1965-re felszámolták). Az operatív irányító tevékenységet igazgatási, hatósági, szabályozási feladatok ellátása váltotta fel, 1968-tól pedig a népgazdaság egészében ilyen irányba módosult a tervgazdaság.

A járási kirendeltségek számára - megalakulásuktól kezdve - folyamatos feladatot jelentett a népmozgalmi statisztikák vezetése, begyüjtötték és ellenőrizték a jelentések adatlapjait (születés, házasság, haláleset). Az Állami Népességnyilvántartó Hivatal megalakulásával, 1984 első napjától kezdve ennek az intézménynek a feladata lett a népmozgalmi lapok gyüjtése és gondozása. A járások száma a közigazgatás átalakítása miatt országosan folyamatosan csökkent: 1966-ban 118, 1980-ban már mindössze 83 járás müködött. Ezzel párhuzamosan apadt a statisztikai felügyelöségek száma is, mígnem a közigazgatási egységeket felszámolták, s ezt követve a KSH 
elnökének utasítására 1980. december 31-i hatállyal mindegyiket megszüntették, lehetővé téve, hogy néhány helyen 1983 végéig területi felelősök dolgozzanak.

Ezt megelözően a felügyelőségek az igazgatóságokkal együtt nagy szerepet játszottak az egyszeri országos összeírásokban: az 1960. évi és az azt követő négy népszámlálás lebonyolításában, akárcsak a közéjük eső években megtartott mikrocenzusok végrehajtásában, valamint az ÁMÖ-ben (általános mezőgazdasági összeírás) is. Ez utóbbit első alkalommal 1972-ben, két szakaszban végezték: júliusban a nagyüzemi gazdaságok belső viszonyaira, a következő év első negyedévében a szövetkezeti parasztság foglalkoztatottságára, munkavégzésére vonatkozó adatokat gyüjtötték.

A gazdaságirányításban bekövetkezett irányváltás vonta magával az ármegfigyeléseket, ami végső szakítást jelentett az 1951 óta kizárólag technikai jellegü, elszámolási egységként szolgáló tervárak (termelői árak) és a fogyasztási (kereskedelmi) árak rendszerével, a mezőgazdaságban hasonlóképpen különültek el a beszolgáltatási és a piaci árak. A piaci ármegfigyelések 1965-től kezdődtek a megyék kijelölt községi piacain. Két évre rá a kiskereskedelmi árak reprezentatív megfigyelése is beépült az adatgyüjtési rendszerbe, forrásként első időkben a boltok árjegyzékei szolgáltak, ám 1972-től árösszeírók rögzítették az egységárakat meghatározott kijelölt boltokban, 1983-tól kiegészülve a zöldségboltokkal és a vendéglátóegységekkel, három évvel később a magánkereskedőket is bevonva a megfigyelt egységek körébe. A munkát az igazgatóságok állományába tartozó árfelírók végezték. Ismeretes, hogy a fogyasztói árak megfigyelése 1992 után megújult.

Az új gazdasági mechanizmus, az eredeti elgondolások szerint, társadalmipolitikai reformokat is előirányzott. Az életkörülmények vizsgálatát az 1949 végén megkezdett háztartási megfigyelésekkel indította a KSH. A területi szervek mindegyike állandó összeírók részvételével 1955-től kapcsolódott be a háztartások folyamatos vizsgálatába, Az életmód kérdései az 1960-as években kerültek elötérbe, majd a lakosság megfigyelésére vonatkozó igények sokaságát 1976 januárjától az ELAR (egységes lakossági adatfelvételi rendszer) bevezetésével oldotta meg a hivatal, amit az adatfelvételi bázis, a fogalmak, valamint az adatfeldolgozás és -tárolás rendszerének egységesítése kísért (minden igazgatóság forradalmi változásként értékelte a váltást). Az egyik ágon háztartásstatisztikai felvételek, a másikon munkaerövizsgálatok és ehhez kapcsolódó társadalomstatisztikai felmérések zajlottak; az utóbbiakat pályatörténeti, egészségügyi, jövedelmi felmérések kísérték, továbbá az időfelhasználást, az üdülési, utazási szokásokat vizsgálták, adatokat gyűjtöttek a magánkisipar szolgáltatásairól. A feladatok végzésére önálló ELAR-csoportok jöttek létre (1986-tól összeírási osztályok lettek). A rendszert 1983 januárjától új, integrált mintával átszervezték, módot nyitva az összeírók számának csökkentésére, az adatok területi felhasználhatóságának reményében. A háztartási költségvetési felvételek 1992 után váltak folyamatossá. 
Az 1989 utáni gazdasági-társadalmi átalakulások nyomán megszaporodtak a termelés megfigyelésének egységei, ami kivételes, egyszeri összeíráshoz vezetett: a gazdasági szervezetek teljes körű összeírását eredményezte 1997. május 1. és június 30. között, ennek alapján megújult a GSZR (gazdasági szervezetek regisztere).

\section{A tájékoztatás}

Bár az 1952. évi statisztikai törvény a tájékoztatást is az új területi szervek feladataivá tette, a nehézségekkel kikövezett indulás miatt érdemi elörelépés ezen a téren csak később következett be, amikor a KSH elnöke is elérkezettnek láthatta erre az időt. Péter György 1953-ban „Összehívott egy szük körủ megbeszélést és azt kérdezte, van-e elképzelésem, mit kell tenni az igazgatóságokkal és a felügyelőségekkel. Maradjanak-e ezek adatgyüjtő és -feldolgozó egységek, amelyek a központ keze alá dolgoznak?" - idézte fel a döntés előzményeit 46 évvel később Barabás Miklós, aki szerint kár lett volna feldolgozatlan információkkal ellátni az adatfelhasználókat, inkább egységes szerkezetben lenne érdemes feldolgozni és nyilvánosságra hozni az adatokat. Barabás Miklós (1921-2009) a területi statisztika meghatározó alakja volt: a KSH Területi főosztályán osztályvezető, majd 1957 tavaszától 28 éven át vezette a főosztályt, emellett ő volt a Területi Statisztika folyóirat alapítója. Indítványát 1953ban Péter György „,szimpatikusnak, csak kicsit utopikusnak találta, mondván, túlhalad mindent, amit addig a területi szervekről gondoltak". (Marosi [2010b]) Ezzel együtt a statisztikai munka színvonalának emelésére 1954-ben, MT-határozat alapján központi előadó névvel, önálló tájékoztatási munkakört szerveztek.

A tájékoztatás a helyi vezetés informálását szolgálta; az első években a KSH konkrét elöírásokkal látta el a kirendeltségeket a közlési módok tartalmára, formájára, megjelenési időpontjaira vonatkozóan. A tevékenység emellett nem nélkülözte a legmagasabb szintu” „elvi” irányítást sem: az MSZMP (Magyar Szocialista Munkáspárt) Politikai Bizottsága 1958-ban áttekintette a területi statisztikai szervek müködését, és az elemzések elmélyítésére, a népszerü kiadványok számának növelésére szólította fel az érintetteket. A párt titkársága a területi igazgatóságok információellátásának kérdései között 1969-ben és 1977-ben is tárgyalta a további fejlődés stratégiai teendőit, előbb meghatározó szerepet adva nekik a megyei pártbizottságok tájékoztatásában, majd 1977-ben különös súlyt fektetve a vállalatsoros információszolgáltatásra és a területfejlesztési tervek megvalósításának követésére. A KSH főosztályvezetői értekezlete a nyolcvanas években háromszor is részletezte a tennivalókat, főleg a tájékoztatás rugalmasságának, gyors reagálásának szükségességét emelve ki. 
Kezdetben a tanácsok és a pártbizottságok a rájuk rótt gazdaságirányítási feladatok ellátásához saját forrásaikból merítették az adatokat, a KSH szervezeteinek munkáját három-négy év alatt sikerült elismertetni. Igaz, előfordultak szórványos kísérletek egy-egy megye helyzetének áttekintésére: Hajdú-Bihar megyében már 1951 júliusában összeállítottak egy összefoglaló jelentést, ám a személyi feltételek alakulása, azaz a munkatársak felkészültsége még három évvel később sem kedvezett a folyamatos tájékoztatás megindításának, amely egyébként 1957-ig titkos minősítésü volt. Az önállósult igazgatóságok 1954 derekáig ágazatonként készítették rendszeres jelentéseiket, negyedévenként öt-hat különböző témában. Minthogy azonban a táblázatok sokaságát tartalmazó beszámolókkal „,a fától nem lehetett látni az erdőt”, ezeket a jelentések túlburjánzásának megszüntetése jegyében - felváltották a jóval tömörebb összefoglalók, amelyek végigkísérték az igazgatóságok életét. A 120-150 példányban sokszorosított közlemények eleinte több, idővel viszont kevesebb táblázattal készültek, az év utolsó negyedében az esztendő összefoglalását is tartalmazták, és „szolgálati használatra" jelzéssel láttak el őket; idővel ez a minősítés mind ritkábban jelent meg, 1983-tól végleg elhagyták. Ezen kívül például Győr-Sopronban 1958-tól, a megyei vezetők minél gyorsabb tájékoztatása érdekében, igen rövid kivonatok is készültek, „feljegyzések” elnevezéssel. A kiadványok 1963-től „időszerü kérdések” elnevezésü fejezettel gyarapodtak, majd öt évvel később új követelmények léptek fel velük szemben, ezek értelmében a negyedéves tájékoztatókat kétfelé osztották: a termelésre vonatkozó, illetve a lakosság életkörülményeit elemző részre. A negyedéves jelentéseket országosan egységes formában és tartalommal megjelenő beszámolók egészítették ki, amelyek tartalmazták az országos és a szomszédos megyék adatait is. A negyedéves jelentések rövid, tömörített változatai fokozatosan megjelentek a megyei napilapok hasábjain is.

Bár ez a kötelezettségük 1957-ben megszünt, az 1960-as évek közepéig jelentős szerepet játszottak a helyi vezetők tájékoztatásában a járási felügyelőségek is, ún. „témajelentések” összeállításával, amelyek elsősorban a mezőgazdasági termelésről, a népmozgalomról, az építőiparról szóltak, az agrárösszeírásokat követően a felmérésekről táblázatos közléseket készítettek. Ilyen irányú tevékenységük 1964-ben ért véget, ettől fogva a járási adatokat részletesen is tartalmazó kiadványok az igazgatóságokon készültek.

A tájékoztatás felkészült, jellemzően közgazdász végzettségü munkatársak közremüködését igényelte. Az első évek nehézségeit követően számuk gyarapodott; az igazgatóságokon belül előbb ún. központi előadókként dolgoztak, az 1965. évi szervezeti átalakítások nyomán pedig a tájékoztatási osztályok munkatársaiként.

A megyék helyzetéről 1956-tól zsebkönyvek láttak napvilágot, az első számok az 1952 és 1955 közötti (illetve 1950-ig visszatekintő) időszak adataival, akárcsak az 1957-től meginduló megyei évkönyvek esetében. Ezek készítése csak 1961-től vált kötelezővé. Kiadásukban változást hozott 1975: szerkezetük azzal a szándékkal mó- 
dosult, hogy megteremtsék a jövőbeli, 1976 és 1980 közötti évek adataihoz szükséges bázist, adatbázisként szolgálva a tervezés és irányítás számára, hogy egy-egy tervidőszak folyamán az évkönyvek változatlan struktúrában álljanak rendelkezésre. Az 1970-es évek derekán megjelentek a tekintélyes terjedelmü, tíz-húsz év adatait tartalmazó, következésképpen ezer oldalt elérő ágazati adattárak is.

A két kongresszus között egységes címmel jelent meg 1975-ben az a publikáció, amelyet minden igazgatóság kiadott, részletes elemzést készítve az adott megye társadalmi-gazdasági fejlődéséről. Hagyományőrző kiadvány volt: 1959-ben „Számvetés az MSZMP Kongresszusa előtt" címmel adták ki első változatát, amelyet azután meg-megismételtek, átfogó szöveges értékelést kínálva a közigazgatási egységekröl. A kongresszusokat megelőző megyei pártértekezletek küldöttei részére pedig „A ... megye számokban", rövid szöveggel, grafikus ábrázolással szemléletessé tett publikációkat készítettek. A párt mellett a tanácsok is megkülönböztetett figyelemben részesültek: a választások elött esetenként külön kiadványok jelentek meg, és hasonló körképet nyújtottak az egyes megyék állapotát számokban tükröző „Helyzetképek" sorozat darabjai is.

A rendszeres, munkatervben szereplő kiadványokat alkalmi publikációk kísérték. Témaválasztásaikban mind a KSH központjától érkező ösztönzők, mind a helyi kezdeményezések szerephez jutottak, az új gazdasági mechanizmus bevezetése után egyre nagyobb figyelmet kapott bennük a lakosság életkörülményeire vonatkozó tények ismertetése, módosítva az első évtized különkiadványaiban kimutatható mezőgazdasági és ipari témák háromnegyedes részesedését. A gazdasági kérdések az időszerüség jegyében kerültek terítékre: a hetvenes évektől a közgazdasági szabályozók hatásairól, a vállalatok hatékonyságáról, a termelési szerkezet átalakulásáról, a nagyüzemek differenciálódásáról készültek elemzések. Megkezdődött a megyeszerkezettől független munkaerö- és kereskedelmi vonzáskörzetek vizsgálata.

Az alkalmi kiadványok a megyei sajátosságokat, adottságokat mutatták be, gyors adatközléseket nyújtottak az új városokról, az államigazgatás területi átszervezésének hatásairól, az időszerü jelenségekről (például „Az árvíz hatása a Szamos-közben élő lakosság életkörülményeire" 1971-ben). Az 1960-as években társigazgatósági összefogással is készültek publikációk.

A tágan értelmezett tájékoztatáshoz a hivatalon belüli kommunikáció is hozzátartozik. Ennek egyik eleme az igazgatóságok közötti kapcsolatok alakulása volt. A közöttük megvalósuló információáramlást fellendítette a Magyar Közgazdasági Társaságon belül 1966-ban alakult Statisztikai szakosztály tevékenysége, ezen belül is a 170 taggal létrejött Területi statisztikai szekcióé. Regionális elvek alapján hét, szomszédos megyéknek helyet adó munkacsoport keletkezett a tagozatban, amely a területi pártszervek, tanácsok, megyei tudományos kutatóhelyek munkatársainak bevonásával vitaüléseket szervezett, alkalmat kínálva a kapcsolatteremtésre, a fiatal munkatársak beilleszkedésére. 
A belső kommunikáció csatornájaként a Területi Statisztika folyóirat szolgált. Elődjének az 1951 júniusában jelentkező Statisztikai Értesitô, a helyi tanácsoknak is szánt, ,a megyei, járási és városi statisztikai csoportok közötti élő, hasznos kapcsolatok kiépítését" szolgálni kívánó kiadvány tekinthető. Első számában olvasható a figyelmeztetés: „Felhívjuk olvasóink figyelmét, hogy a Statisztikai Értesítő díja negyedévre 1,50 Ft. A Népgazdasági Tanács határozata értelmében a lapot ingyen nem terjeszthetjük" (Novák [2010]). A lap utolsó száma 1956 szeptemberében jelent meg. Fél évvel később „Megyei és Városi Statisztikai Értesitö" címen a folyóirat új életre kelt, a területi szemlélet kialakításának igényét fogalmazva meg olvasói körében, a korábbi 16 helyett 60 oldalas terjedelemben, 1963-tól nívódíjjal ismerve el a kiemelkedő publikációkat. Ez a lap vette fel 1968-tól a Területi Statisztika elnevezést, és évi hat alkalommal jelentkezett, 120 oldalon teret adva a területi szervezeteknél dolgozó munkatársak írásainak. A folyóiratnak az is célja lett, hogy az interdiszciplináris megközelítés jegyében maga köré gyüjtse az ország településhálózatának helyzete és fejlesztése iránt elkötelezett nem statisztikus szakembereket (területi tervezőket, földrajztudósokat, regionális kutatókat, közigazgatási szakembereket).

\section{A „gyaloglópénztől” az online kapcsolatig}

A területi statisztikai szervek hőskorában az információk közvetítése jelentős élőmunka ráfordításával valósult meg, emberi erőfeszítésekkel kellett áthidalni a kor infrastruktúrájának hézagait. Visszatekintve, a hivatalon belüli adatáramlás is körülményes volt: Budapestre kellett utazni egy-egy adat kigyüjtéséért, ellenőrizéséért. A megyében pedig a statisztikus felkereste az adatszolgáltatót, elérte a kérdőív kitöltését: a számviteli-bizonylati fegyelem szinte ismeretlen fogalom volt, a kérdőívek többségét a statisztikus a helyszínen tölthette ki, ahova valahogyan el kellett jutnia. Az ötvenes évek elején a községek közötti közlekedés kimondottan nehézkes volt: utaskilométer alapján a távolsági személyszállításból az autóbuszok 1950-ben kereken százezer utast fuvarozva, 5,2 százalékkal; 1970-ben is csupán 30,1 százalékkal részesedtek. Maradt a kerékpár, a motorkerékpár, kivételes esetekben a taxi (az ország személygépkocsiállománya a területi szervek megalakulásának évében 9472 darabot számlált) ( $K S H$ [1996]). A szerencsésebb munkatársak kerékpár segítségével végezték munkájukat (néha napi 25-30 kilométert küzdve le), míg mások gyalogoltak. Érthető tehát, hogy esetenként „gyaloglópénz" kifizetésével ösztönözték a statisztikusokat, mint tették azt Komárom megyében, ahol kilométerenként 25 fillért számoltak el. A felügyelöségek 1953 és 1955 között Csepel motorkerékpárokat kaptak, a következö évtized elejére pedig teljesen „motorizáltak” lettek. A közlekedési feltételek javulásával, a feladatok 
összetételének változásával a motorkerékpárok használata fokozatosan megszünt. Az első személygépkocsikat az igazgatóságok 1959-ben kapták.

Az állami vállalati kérdőívek, a tanácsok alá tartozó ipari, kereskedelmi vállalatok, egészségügyi és kulturális intézmények, könyvtárak kérdőíveinek begyüjtését az ellenőrzés, majd a feldolgozás követte, természetesen kézi úton. Végül az összesítöket írásos összefoglalók kíséretében továbbították a KSH illetékes osztályaira.

Mindezt mostoha tárgyi feltételek között tették. Induláskor a tanácsoktól kapott irodákban vagy iroda céljaitól idegen helyiségekben (üzletekben, lakásokban) zajlott a munka, a tanácsoktól örökölt bútorok között, amelyeket csak az 1960-as években kezdtek el cserélni. Sok helyen már egy cserépkályha is örömöt okozott, mert jobban tartotta a hőt, mint a vaskályhák. A tájékoztatást nem segítette, hogy a kiadványok készítése és kiadása, a gépelés, sokszorosítás, kötés technikai vonatkozásban is alapvetően az igazgatóságokra hárult: kézi hajtású, majd villanymotoros stencilgépek segítségével birkóztak meg a feladatokkal, úgyhogy valóságos megváltást hozott 1970, amikor az akkor legmodernebb Rank Xerox sokszorosítógépek állhattak munkába.

Az igazgatóságok első éveit költözések terhelték; az első önálló irodaépülete Fejér megyének volt, az 1960-as évek elején új irodaházat kapott Csongrád és Vas megye is. A következő évtizedben a minden megyében központot fenntartó SZÜV-vel (Számítástechnikai és Ügyvitelszervezési Vállalattal) közös irodaépületek létesültek; ezt a sort Tatabánya nyitotta 1979-ben. (,...amikor a SZÜV megyei központjai épültek, akkor hogy, hogy nem, mindig egy emelettel magasabb épületek keletkeztek, és ebben helyezkedtek el a KSH igazgatóságai") (Lakatos [2009]). A legmagasabb épületbe ugyanakkor a Baranya megyei igazgatóság került, mégpedig a pécsi, 2016ben lebontott, 84 méteres magasház alsó két emeletére.

A számítástechnika fejlődése forradalmi változásokat hozott a megyei igazgatóságok életébe is. Az út a százalékszámítást megkönnyítő logartáblák, logarlécek használatától a kézi múködtetésủ mechanikus számológépek (Brunschwiga, Triumphator) alkalmazásán keresztül, a hatvanas évek első felétől terjedő elektromos számológépeken át vezetett; ilyenek voltak az Német Demokratikus Köztársaságban kifejlesztett Reinmetall, Triumph, Mercedes típusú mechanikus és félautomata gépek. A nagy és hangos szerkezetek elnyühetetlennek bizonyultak (ezeket becézték „traktoroknak”, szemben a „tekerőkként” emlegetett kézi gépekkel). Következtek a kézi kartonokat felváltó Optimatic könyvelögépek (közülük Komáromba 1961-ben érkezett meg az első, míg Baranya az 1960-as évek végén jutott hasonló szerkezethez). A következő évtizedben megjelentek az első elektronikus összeadógépek, 1980 után pedig a munkatársakat elektronikus zsebszámológépekkel látták el.

A szövetkezetstatisztikai feladatok 1968-as átvétele a mezőgazdasági és a kisipari szövetkezetek megyei központjaitól a tennivalók megsokszorozódását jelentette, ellátásukra lyukszalag-technikával müködő Olivetti komputerek tüntek fel az igazgatóságokon. Fokozatosan állították üzembe a képernyő nélküli Audiotronic 770 szá- 
mítógépeket, amiket Audit 1642 típusú könyvelőgépek követtek, módosítva egyben a feldolgozási osztályok szervezeti felállását is. Tíz évi üzemeltetésüket követően, a mikroprocesszorok tömeges elterjedése új gépek alkalmazását vonta maga után, a 768 kB tárkapacitású, terminálokkal is rendelkező TPA 1140 „elektronikus számítástechnikai gépekét" (a rövidítés a Központi Fizikai Kutatóintézet által kifejlesztett tárolt programú analizátorokat fedi). Ezzel a számítástechnika a statisztikusok mindennapjainak része lett, fokozatosan be lehetett vezetni a kérdőívek gépi ellenőrzését. A gépek munkája nagyjából fele-fele arányban oszlott meg a helyi igények teljesítése és a KSH központja részére végzett tevékenységek között: az ellenőrzött adatállományokat mágnesszalagokon továbbították, majd a távközlési hálózatba bekapcsolódva kialakították a közvetlen összeköttetést is. Lehetővé vált az adathordozók teljes elökészítése a központi összesítésre, eleget lehetett tenni az igazgatóságok tájékoztatási tevékenységéhez szükséges feldolgozási igényeknek, és tárolhatóvá, könnyen kezelhetővé váltak az ehhez nélkülözhetetlen idősorok.

A TPA-gépek 1984-ra véget ért üzembe állítása légkondicionált termeket igényelt, kezelésük pedig szakértelmet: megkezdődött a számítástechnikai ismeretek terjedése a statisztikusok körében, ami új szakemberek felvételével és tanfolyami oktatásokon keresztül valósult meg. A folyamat nyomot hagyott az igazgatóságok szervezeti felépítésén is: számítástechnikusok alkalmazásával kibővítve önállósultak a feldolgozási osztályok.

Az elektronikus gépeknek, a hatékonyabb feldolgozási eljárásoknak hála, mindez az adattömegek kezelésében minőségi változáshoz vezetett: Az 1974. évtöl fokozatosan kidolgozták a STAR-t (statisztikai adatbázisrendszereket); ennek területi része a T-STAR lett.

Az informatika elöretörésének következő lépcsőfokait az UNIX-ORACLE egységes környezetre építő megoldások képviselték. Ez a - metaadat-vezérelt adatgyüjtés-független alkalmazások fejlesztésével, az első szakaszában adatgyüjtésszervezéssel és metaadat-kezeléssel kezdődött - folyamat 1997-re zárult le; később mérföldkőnek bizonyult az ELEKTRA online adatközlési mód bevezetése.

A folyamat a manuális adatgyüjtési és feldolgozási eljárások fokozatos elsorvadásához vezetett, jelentékenyen módosítva a területi szervezetek munkatársainak a statisztikák elöállításában betöltött szerepét.

\section{A rendszerváltozás után}

A megyei tanácsok helyébe lépő megyei önkormányzatok, közgyülések felhasználókként az új feltételek között elödeiknél csekélyebb igénnyel léptek fel: kötelező

Statisztikai Szemle, 95. évfolụam 11-12. szám 
feladataik többségét elsősorban oktatási, egészségügyi, környezetvédelmi ügyek alkották, ezzel együtt megnőtt szerepük a területfejlesztésben. Az adatok felhasználói között megjelentek a gazdasági élet szereplöi (a Magyar Kereskedelmi és Iparkamara megyei tagozataitól a külföldi befektetőkig). A változások nyomán így az 1990-es évek folyamán módosult a megyék határai közé eső tájékoztatási tevékenység, és felértékelődött a nyilvánosság, a média szerepe: a központban változó elnevezésekkel sajtó- és kommunikációs részleg létesült, munkája megfelelőit az igazgatóságokon a tájékoztatási osztályok munkatársai látták el.

Az 1989 utáni változásokat a KSH szervezete úgy követte, hogy 1992-ben megszünt a Területi statisztikai és önkormányzati föosztály, a területi statisztika feladatai a Környezeti és területi statisztikai föosztály elnevezésủ részleghez kerültek, továbbá egyesítették a fövárosi és Pest megyei igazgatóságokat. Az összevont igazgatóság vezetését 1996-ig Kovács Tibor látta el, aki hat évvel később (már a Területi tájékoztatási osztály vezetőjeként) ünnepi megemlékezést szervezett a területi kirendeltségek megalakulásának 50. évfordulója alkalmából.

Kovács Tibor (1935-2004) példaszerüen művelte a területi- és településstatisztikát, amelyet a komáromi éveket követően, a Vas megyei igazgatóság élén 1960 és 1970 között kezdett meg. A tájékoztatási tevékenységben betöltött különböző posztokon pártfogása alatt igazgatóságok elemzőinek nemzedékei nőttek fel. A félévszázados megemlékezés idején, a 2001. évi népszámlálás lebonyolításának tapasztalatai alapján a KSH elnöksége már úgy vélte: nehézkessé, akadozóvá lett a kommunikáció a központ és a megyék között (a cenzus első eredményeinek terjesztése nem alakult kielégítően; volt olyan megye, ahova hónapos késéssel jutottak el a megfelelő anyagok).

Az egyébként is időszerűvé váló szervezetátalakítási hullám nyomán 2005. január 1-jével megszüntek a KSH megyei igazgatóságai, helyettük regionális központok jöttek létre Debrecenben, Győrött, Miskolcon, Pécsett, Szegeden és Veszprémben, amelyekhez a megyeszékhelyeken képviseletek tartoztak. A cél kompetenciaközpontok kialakítása, létrehozása volt. Az átalakítás során ügyeltek az adatgyüjtés zökkenőmentes folytatására: a 722 fős területi apparátusból összesen 175 fö, miközben az adatgyüjtésben közvetlenül érintett 431 fö közül csak 18 munkatárs távozott (a KSH létszáma 2005-re 1848 före apadt a két évvel korábbi 2122 fős csúcsot követően). Ezzel egyidejüleg vidéken 100 fó távmunka keretében folytatta a munkát, amit a csoportos ingázások rendszerének bevezetése egészített ki. Egyes bírálatok szerint az átszervezés úgy zajlott, hogy megelőzte a szervezeti és müködési szabályzat megalkotását, tisztázatlanul hagyva az új rendszer elemeinek, nevezetesen a központ és a régiós igazgatóságok egymáshoz való viszonyát.

Kiigazításként 2011 februárjától a hat igazgatóság megtartása mellett, a megyeszékhelyeken osztályokká szervezve ismét müködni kezdtek a KSH területi szervei. Tevékenységüket a 2017 elején életbe lépett átalakítás módosította, és új tartalommal, új feladatmegosztással látta el őket. 


\section{Irodalom}

DÁNYI D. - NYITRAI F.-NÉ (szerk.) [1998]: Tanulmányok a magyar statisztikai szolgálat történetéböl. Központi Statisztikai Hivatal. Budapest.

FELLEGI, I. P. - RYTEN, J. [2002]: A magyar statisztikai rendszer szakértői vizsgálata. Statisztikai Szemle. 80. évf. 2. sz. 107-185. old.

HoRVÁTH T. [1963]: Kísérletek a területi statisztikai szervezet létrehozására 1867 után. Statisztikai Szemle. 41. évf. 8-9. sz. 865-871. old.

KSH (KöZPONTI STATISZTIKAi HivatAL) [é.n.]: A területi szervek 35 éve. Budapest.

KSH [1987a]: A Központi Statisztikai Hivatal Baranya megyei igazgatóságának megalakulása és müködése 1952-1987. Pécs

KSH [1987b]: A Központi Statisztikai Hivatal Vas megyei igazgatóságának 35 éve. Szombathely.

KSH [1987c]: A KSH Nógrád megyei igazgatósága történetének 35 éve. Salgótarján.

KSH [1996]: Magyarország népessége és gazdasága-Múlt és jelen. Budapest.

Lakatos M. [2009]: Beszélgetés Pesti Lajossal. Statisztikai Szemle. 87. évf. 3. sz. 312-317. old.

Marosi L. [2010a]: Egy emberöltő földközelben. Dr. Lukács Pál ír kávé mellett. Területi Statisztika. 50. évf. 4. sz. 383-397. old.

Marosi L. [2010b]: Pályaív, védett területen. Barabás Miklós főszerkesztő visszaemlékezése. Területi Statisztika. 50. évf. 1. sz. 12-21. old.

MóD A.- NÉ [1951]: A mezőgazdaság területi statisztikájának időszerű kérdései. Statisztikai Szemle. 29. évf. 12. sz. 1069-1080. old.

NovÁK Z. [2010]: Múltidézés: a Területi Statisztika az ötvenes évtizedben. Területi Statisztika. 50. évf. 1. sz. 6-11. old

PÁLos I. [1952]: A beszámolási rendszerről. Statisztikai Szemle. 30. évf. 4. sz. 261-262. old.

\section{Summary}

Establishment of the territorial units of the HCSO (Hungarian Central Statistical Office) in 1952 was intertwined with the increased demands of the planned economy, a Soviet-style system introduced four years before. The founding of local statistical branches also coincided with the reform of the state administration, giving birth afterwards to the statistical directorates in counties and sub-offices in the districts. The paper depicts their outstanding role in the strict command economy of the first years when data collection and check occurred in frequently asked intervals. Later, with loosening of the planning system, their role changed accordingly, getting them involved in societal data collection as well as in the dissemination of territorial level statistics. By the progress of computing techniques, the scope of directorates' activity was broadened with first-stage data processing during the 1970s. Transition of the political and economic landscape after 1989 together with the spread of information technology involved radical changes in the role of the HCSO's local branches, resulting in their reshaping first in 2005, then in 2011 up to the reforms of our days, concerning the whole organisational structure of the HCSO. 